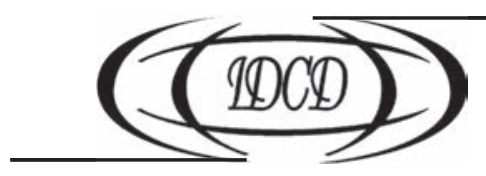

https://doi.org/10.15407/dse2017.02.089

УДК 314.174 (477)

JEL CLASSIFICATION: R23, J61

\title{
O.V. POZNIAK
}

$\mathrm{PhD}$ (Economics), Senior Researcher

Ptoukha Institute for Demography and Social Studies

of the National Academy of Sciences of Ukraine

01032, Ukraine, Kyiv, Blvd. Taras Shevchenko, 60

E-mail: olex_poznyak@ukr.net

\section{TRANSFORMATION OF POPULATION MIGRATION IN UKRAINE AFTER COLLAPSE OF THE SOVIET UNION}

The article deals with transformations of migration processes that have been occurring in Ukraine after the collapse of the USSR. A periodization of the migration processes development in Ukraine since independence is presented. During the first years after Ukraine gained independence, migration processes were related mainly to returning of migrants including returning of victims of Soviet political repressions and the Soviet population redistribution policy. Accordingly Ukraine experienced a large migration growth of the population. Development of external labor migration flows took place in the middle of the 1990s. The reasons of labor migration development are illustrated. A distribution of Ukrainian migrants by country of their destination is specified. The leadership of the Russian Federation in terms of number of Ukrainian migrants in the 1990s is explained.

Dramatic events that took place in Ukraine in 2014-2016 made an impact on all aspects of social development in the country. Among others, Ukrainian migration situation has been changing permanently. The intensity of labor migration from Ukraine has been increasing. Reorientation of Ukrainians from Russia to the $E U$ member states is noted. The reasons for these processes are presented in the paper. Resettlement of internally displaced persons in Ukraine is analyzed. The author proposes recommendations for improving the state migration policy of Ukraine in the current situation.

Keywords: migration, labor migration, internally displaced persons (IDPS), periodization of migration processes development

\section{О.В. Позняк}

канд. екон. наук, старш. наук. співроб.

Інститут демографії та соціальних досліджень

ім. М.В. Птухи НАН України

01032, м. Київ, бул. Т. Шевченка, 60

E-mail: olex_poznyak@ukr.net

\section{ТРАНСФОРМАЦІЯ МІГРАЦІЇ НАСЕЛЕННЯ}

\section{В УКРАЇНІ ПІСЛЯ РОЗПАДУ РАДЯНСЬКОГО СОЮЗУ}

Розглянуто трансформації міграційних процесів, що відбуваються в Україні після розпаду СРСР. Представлено періодизацію розвитку міграційних процесів в Україні з моменту здобуття незалежності. У перші роки після здобуття Україною незалежності міграційні процеси були пов'язані переважно 
з поверненням мігрантів, у т. ч. жертв політичних репресій та радянської політики перерозподілу населення. Відповідно, в Україні спостерігався значний міграційний приріст населення. Становлення потоків зовнішньої трудової міграції відбулося в середині 1990-х років. Викладено причини розвитку трудової міграції, показано розподіл українських мігрантів за країнами призначення. Пояснено лідерство Російської Федерації за кількістю українських мігрантів в 1990-х роках.

Драматичні події, що відбулися в Україні в 2014-2016 роках, вплинули на всі аспекти соціального розвитку країни. Міграційна ситуація в Україні постійно змінюється, а інтенсивність трудової міграції з України збільшується, причому помітна переорієнтація українців з Росії на країни-члени ЕС. Висвітлено причини цих процесів. Проаналізовано переселення внутрішньо переміщених осіб в Україні. Запропоновано рекомендації щодо вдосконалення державної міграційної політики України в ситуації, що склалася.

Ключові слова: міграція, трудова міграція, внутрішньо переміщені особи, періодизація розвитку міграційних процесів.

\section{А.В. Позняк}

канд. экон. наук, старш. науч. сотруд.

Институт демографии и социальных исследований

им. М.В. Птухи НАН Украины

01032, г. Киев, бул. Т. Шевченко, 60

E-mail: olex_poznyak@ukr.net

\section{ТРАНСФОРМАЦИЯ МИГРАЦИИ НАСЕЛЕНИЯ В УКРАИНЕ ПОСЛЕ РАСПАДА СОВЕТСКОГО СОЮЗА}

Рассмотрена трансформация миграционных процессов, происходящих в Украине после распада СССР. Представлена периодизация развития миграционных процессов в Украине с момента обретения независимости. В первые годы после обретения Украиной независимости миграционные процессы были связаны главным образом с возвращением мигрантов, в т. ч. жертв политических репрессий и советской политики перераспределения населения. Соответственно, в Украине наблюдался значительный миграционный прирост населения. Становление потоков внешней трудовой миграции произошло в середине 1990-х годов. Изложены причины развития трудовой миграции. Показано распределение украинских мигрантов по странам назначения, объясняется лидерство Российской Федерации по количеству украинских мигрантов в 1990-х годах.

Драматические события, произошедшие в Украине в 2014-2016 годах, повлияли на все аспекты социального развития страны. Миграционная ситуация в Украине постоянно меняется. Интенсивность трудовой миграции из Украины увеличивается, при этом заметна переориентация украинцев с России на страны-члены ЕС. Указаны причины этих процессов. Проанализировано переселение внутренне перемещенных лии в Украине. Предложены рекомендации по совершенствованию государственной миграционной политики Украины в сложивщейся ситуации.

Ключевые слова: миграция, трудовая миграция, внутренне перемещенные лица, периодизация развития миграционных процессов.

Introduction. During the entire history of Ukraine, the migration processes have been important factors of demographic and socio-economic development. In terms of migration, Ukraine has been a donor country, a recipient country and a transit country too. In the recent years, the role of migration in regional development has increased as a result of the mass movement of internally displaced persons.

Recent research and publications. A lot of attention is paid to the problems of migration in the Ukrainian academic literature. A significant experience of migration researches has been accumulated in works by O. Ivankova-Stetsyuk, E. Libanova, O. Malynovs'ka, I. Maydanik, O. Ovchynnikova, I. Pribytkova, U. Sadova, M. Romanyuk, O. Shul'ga. At the same time, the majority of works are devoted to the current tendencies of migration or analysis of the results of individual surveys. An integrated approach to assessment of transformations, which 
includes periodization, has been applied only in analysis of stationary migration (migration related to the alteration of the official place of residence) [1] or analysis of migration policy [2]. Also, these periodizations were made before the events of 2014. The purpose of this article is to carry out the periodization of the migration history of Ukraine from the Soviet Union collapse to the present time, to reveal the transformation of the migration situation during this period, to assess the future transformations of the migration situation.

Results of research. The main trends in migration of the population of Ukraine during its independence are:

- a large decline in the intensity of the stationary migration, which is related to the official change of residence and are registered by the state statistics;

- reduction of the intensity of migration relations with former USSR republics;

- expansion of contacts with the «old» foreign countries: development of a stable emigration flow to Europe, America and Israel (first, representatives of some ethnic groups - Jews, Germans, Greeks, Hungarians, Czechs etc, later Ukrainians and Russians), rotation of educational migrants from developing countries (people graduating from Ukrainian colleges return to their native countries and are replaced by other people);

- a considerable migration growth in late 1980s and early 1990s, which was replaced by a long period (starting from 1994) of surplus of emigrants over immigrants (by over 100 thousand people a year);

- appearance and development of the new forms of migratory movements for the post-soviet period: labor migration, refugees, transit of illegal migrants, return and settlement of the deported nations; external labor migration was the main form of population migration in Ukraine since mid 1990s until 2014; formation of flow of internally displaced persons (IDPs) and forced migrants from Ukraine since 2014.

During the late XX - early XXI century migration processes in Ukraine have undergone transformations. As a whole, four periods of migration history could be defined in Ukraine since independence; these stages partially overlap:

1. A period of the intensive population exchange between Ukraine and other former Soviet countries: 1991 to mid 1990s.

2. A period of creation and development of labor migrations from Ukraine associated with a decline in migrations related to a change of residence: mid 1990s to early XXI century.

3. A period of stabilization of labor migrations: early XXI century to events of 2014 spring.

4. A period of an increase in external labor migrations and appearance of IDP flows and forced migration abroad: since spring 2014.

In Ukraine significant migration inflow was observed in the early 1990s (the highest increase - about 300 thousand persons - was recorded in 1992). During 1994-2004 Ukraine has been a country of emigration (Fig. 1). The size of migratory losses was 1.2 million persons. Transition to positive net migration occurred in 2005 when the number of immigrants started to grow, while the number of emigrants declined. A small positive migration balance persisted throughout 2006-2011, ranging from 13.5 to 17.1 thousand persons. In 2012, the volume of incoming migration sharply grew, leading to a nearly fourfold increase of the migration balance (to 61.8 thousand persons). However, this was due to regulations which eased the registration of foreigners who came to Ukraine in previous years after the adoption of the Law of Ukraine «On Legal Status of Foreigners and Persons without Citizenship» [3], rather than to a real increase in the number of incoming migrants. Generally speaking, the available statistics reflect the official registration data rather than actual entry data. 


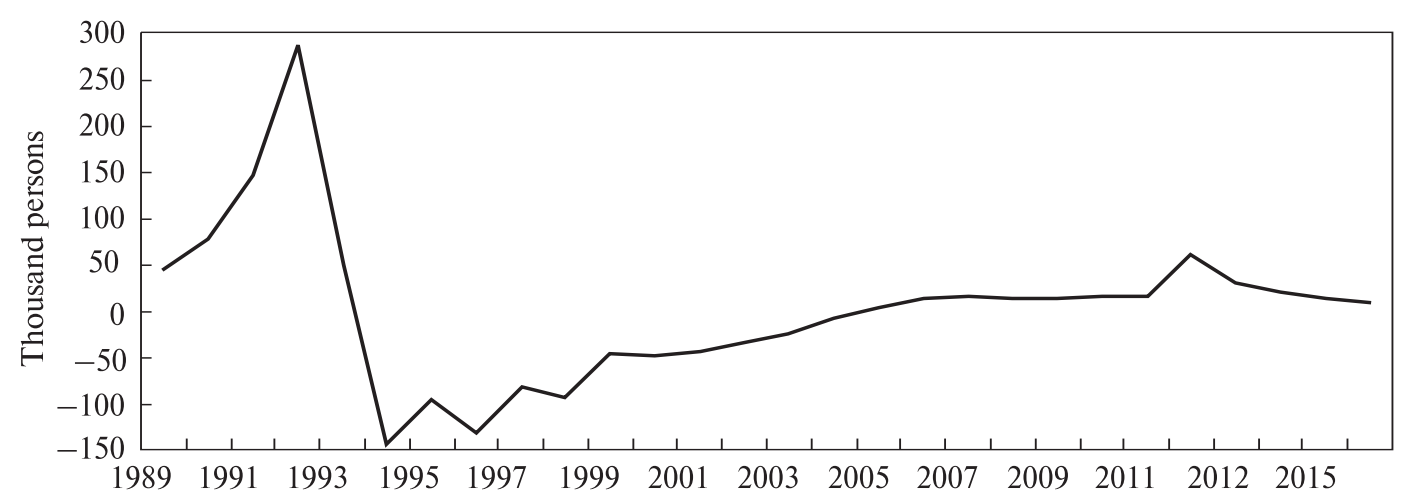

Fig. 1. Dynamics of net migrations of the population of Ukraine in 1989-2016 (according to the current statistics)

Note. Data for the 2014-2016 do not include the temporarily occupied territory of Crimea and Sevastopol. Source: State Statistics Service of Ukraine.

Migration affects the structural characteristics of the population. The total population number of Ukraine has decreased only by $1.0 \%$ as the result of migrations during the period between censuses (1989-2001). The number of men aged 25-29 has decreased by $6.8 \%$, while the number of women of the same age - by $4.9 \%$, of men and women aged 30-34 - by 3.7 and $2.1 \%$ respectively. At the same time, migration processes have contributed to the growth of persons in the age under 20 and over 70, i.e. namely of contingents with very low economic activity. Migration losses of the population of Ukraine have been related almost exclusively to the most economically active contingents. Under absence of migrations during 1989-2001, the population census of 2001 would register a share of persons of the most economically productive age (25-44 years) being $0.5 \%$ higher than the actually registered one, while the demographic dependency rate would be $2.5 \%$ smaller.

Migratory processes have become the main factor of transformations of the ethnic structure of the population. With the disintegration of the USSR and declaration of the independence of Ukraine, the returning of ethnic Ukrainians and representatives of the deported nations (Crimean Tatars, Germans, Greeks, Armenians and Bulgarians) has started from the former Soviet republics. At the same time, a lot of Russians, Belarussians, representatives of other ethnic groups of the «new foreign countries», have returned to the countries of origin. The scales of emigration from Ukraine have largely increased with the removal of the «iron curtain»; while initially mostly Jews, Germans and Greeks have departed, nowadays emigration of representatives of practically all ethnic groups has increased. The economic crisis in the states of Trans-Caucasus had more deteriorated consequences, than in Ukraine, while military conflicts in Caucasus also stimulated inflows of migrants from this region to Ukraine.

Both the natural movement and assimilating processes considerably concede to migrations by the force of impact on dynamics of ethnic structure of the population. This is proven by the data from the censuses of 1989 and 2001. Firstly, the number of Crimean Tatars has grown 5.3 times in Ukraine as the result of the population exchange with the states of the former USSR during 1989-2001, while the number of Armenians - by $84 \%$, of Chechens by $56 \%$, of Abkhazians - by $47 \%$, of Georgians - by $45 \%$, of Azerbaijanis - by $22 \%$; the number of Greeks and Germans, despite their intensive outflow to the historical native 
land, has remained almost unchanged. At the same time, the number of representatives of the majority of ethnic groups of the countries of the former USSR has decreased 1.52 times. Owing to activation of migrations from the Third World countries, the number of persons of Indian and Pakistani origin has increased 8.5 times, of Vietnamese people 8.2 times, of Arabian people - 5.3, of Chinese - 3.3, of Afghans - 2.8 times. The number of Kurds has grown 8.8 times as the result of their arrival from the Middle East and from the former Soviet republics. The processes of entering of the world economic environment by our state, expansion of the international organizations network, creation of joint ventures and branches of foreign companies have caused the repeated increase in the number of representatives of the title ethnic groups of the countries of the developed market economy (of Americans - 64.5 times, of Dutch - 3.2 times, of English and Japanese - almost double, of Frenchmen -1.5 times).

According to the Ministry of Education and Science of Ukraine, more than 53.5 thousand foreign students studied in Ukraine's higher education institutions as of the beginning of the 2015-2016 academic year. The biggest groups of foreign students are from Turkmenistan and Azerbaijan. On the other hand, according to UNESCO, almost 40.0 thousand Ukrainian students studied abroad in 2013 [4] and in 2015 their number increased to almost 60.0 thousand [5].

In 2014, 42 holders of the kandydat nauk degree (an equivalent of $\mathrm{PhD}$ ) and seven holders of the doktor nauk degree left Ukraine. The latter number was decreasing until 2013 and increased since the beginning of conflict on Donbas.

Ukraine remains one of the biggest donors of labor force in Europe. The first national survey on labor migration was conducted by the State Statistics Committee of Ukraine (now - State Statistics Service of Ukraine), together with specialists of Ptoukha Institute for Demography and Social Studies of the National Academy of Sciences of Ukraine (PIDSS of NASU) in the middle of 2008. According to the data, 1.5 million Ukrainian citizens were working abroad during the period from 2005 to the first half of 2008 . That is $5.1 \%$ of Ukraine's population of working age (men 16-59 years old, women 16-54 years old) [6]. The second national survey on labor migration was conducted by the State Statistics Service together with PIDSS of NASU in April - June 2012 on the request of International Labor Organization. According to its results, the number of Ukrainian citizens aged 15-70 years, who were working or looking for a job abroad, was about 1.2 million or $3.4 \%$ of population of relevant age during the period from 1 January 2010 to 17 June 2012 [7]. Both surveys could not include the households, where all family members had migrated and have been living abroad for many years. Also it does not include the persons, who went abroad for work before 2005 (the survey was conducted in 2008) or 2010 (the survey was conducted in 2012) and have not come back to Ukraine. This means that the actual number of Ukrainians working abroad is higher.

Labor migration is more common among men, according to a national survey conducted in 2012; they make up two-thirds of the total number of labor migrants. Most labor migrants are aged 25-49. Those are people who already have some experience and skills and maintain a high level of efficiency at the same time. Attention is drawn to the fact that men engage in labor migration at the age of 25, while women - at 30 years. Obviously, this is caused by the risk of becoming a victim of human trafficking. However, if migration activity among men at the age of $50+$ years old is quickly reducing, there is quite a high level of participation in labor migration among women in pre-retirement and early retirement age. The reason for this is the employment of male workers mainly in physical labor, while women are involved in the work that does not require significant physical efforts. Moreover, after reaching the 
retirement age, Ukrainian women have an opportunity to receive a pension in Ukraine and work abroad at the same time, which causes the current changes in the intensity of labor migration of women of older age.

The village residents make up $54.3 \%$ of labor migrants. The level of the rural population involved in the labor migration at the age 15-70 is 2.9 times higher than the level of the urban population: $6.3 \%$ vs. $2.2 \%$. Higher intensity of external labor migration is observed in the western regions of Ukraine. According to the second national survey conducted in 2012, the residents of seven western Ukrainian regions make up more than $2 / 3$ of the labor migrants. At the same time their share in the total number of economically active population is less than $20 \%$.

The major recipient countries of Ukrainian labor forces are Russian Federation (43.2\%), Poland (14.3\%), Italy (13.2\%) and Czech Republic (12.9\%). Flows of labor migration are also directed to Spain (4.5\%), Germany (2.4\%), Hungary (1.9\%), Portugal and Belarus (by $1.8 \%$ ). By comparing the results of national surveys of 2008 and 2012 an obvious decrease in the proportion of workers in the Russian Federation with increasing intensity of labor migration to EU countries, including the countries of the Visegrad Group, can be determined. In comparison to the survey of 2008, Russia's share has decreased by almost $5 \%$, while the share of EU countries in 2012 (especially Poland) has increased (Fig. 2).

The gradual reorientation of labor migrants from Russia to the EU is an objective process. Factors that contribute to this process are lower economic benefit of migration to Russia compared to migration to the EU, the formation of Ukrainian migration networks and NGOs in the European Union (which makes migration to these countries less risky), and the campaigns for legalization of migrants that were conducted in the EU. There are two main reasons that explain the trend of decrease of Russian share and increase of the EU share in the structure of Ukrainian labor migration. The first one is deterioration of UkrainianRussian relations. The second one is devaluation of the Russian ruble comparing to the euro and the currencies of the new EU member states.

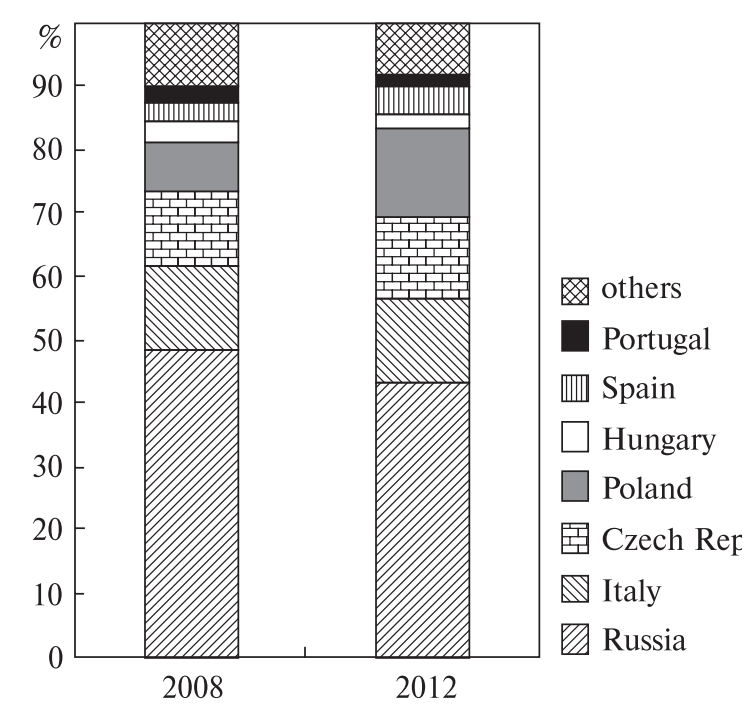

Fig. 2. Distribution of labor migrants by country of destination (last trip), 2008 and 2012

Source: national survey on labor migration in 2008 and 2012. 


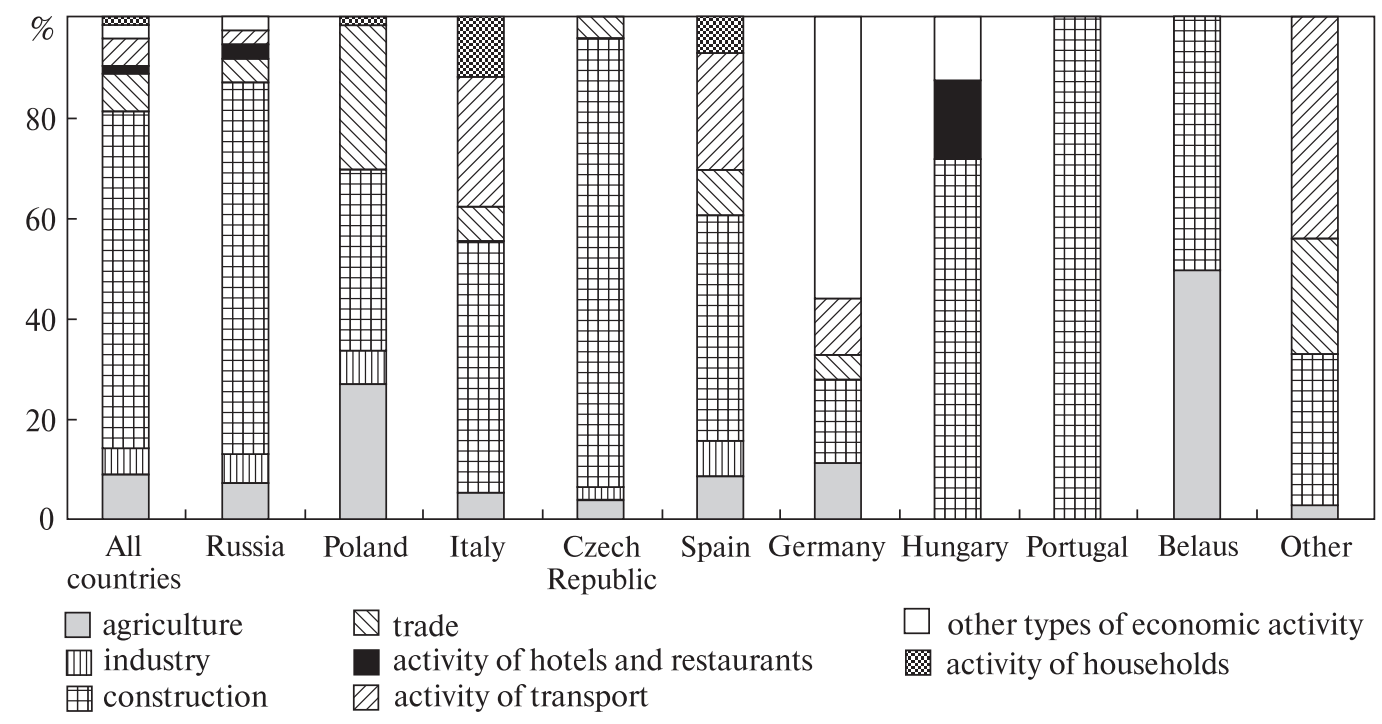

Fig. 3. Male labor emigrants by types of economic activity and countries of migration, 2012

Source: national survey on labor migration in 2012.

Breakdown of migrants by activity type varies substantially depending on gender and the country of stay. In particular, Ukrainian male labor emigrants were mainly engaged in construction. That economic activity type dominates among the men working in Portugal, Czech Republic, the Russian Federation and Hungary (Fig. 3).

For male Ukrainians working in Belarus, construction is one of the two basic activity areas along with agriculture; a high share of persons employed in agriculture is also recorded among those migrating to Poland. Among the Ukrainian men working in Poland, there is a high percentage of those employed in trade; in Hungary, there are high numbers in hotels and restaurants; in Italy and Spain - in household activities; there is high employment of male emigrants in transport.

The employment structure of female Ukrainian emigrants varies considerably depending on the country of stay. Key activities include working as household servants (especially common in Germany and Italy as well as in Spain and Portugal), agriculture (especially in Belarus as well as in Poland and Hungary), trade (mainly in the Russian Federation and Belarus), hotels and restaurants (in Czech Republic and Portugal), and construction (in the Russian Federation, Czech Republic and Hungary). A considerable percentage of those employed in industry is found among emigrant women working in Spain (Fig. 4).

As a result of the annexation of Crimea and Donbas territories, a new type of migration has appeared in Ukraine - internally displaced persons, who caused redistribution of the population among the regions. The total number of citizens of Ukraine, who left Crimea and the area of the anti-terrorist operation (ATO) and moved to other regions as of 16.05.2017 has reached 1175.6 thousand people, according to available information of inter-agency coordination body (ICB) on social security services for citizens of Ukraine displaced from temporary occupied territory and area of the anti-terrorist operation [8]. In addition, several hundred thousand of IDPs stay unregistered. Among the registered persons, 22.9 thousand people come from Crimea, while 1152.7 thousand people (almost $98 \%$ of total number) - 


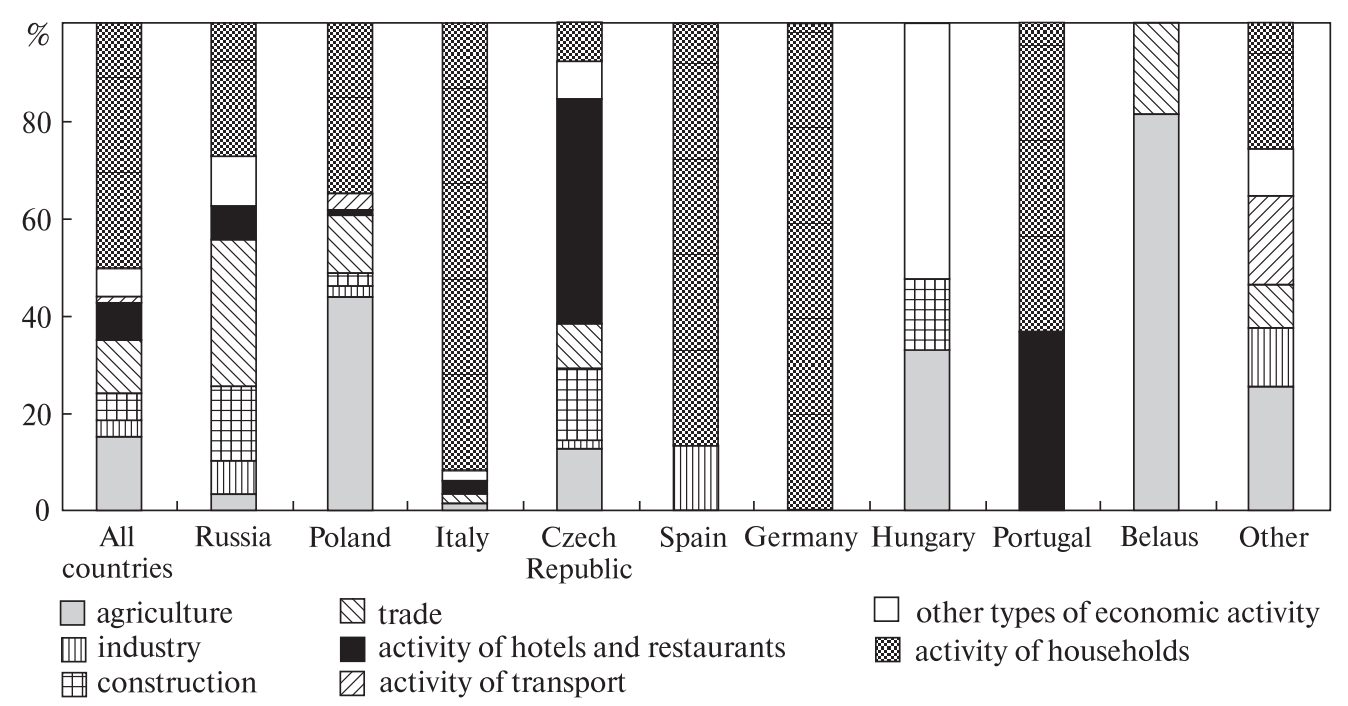

Fig. 4. Female labor emigrants by types of economic activity and countries of migration, 2012

Source: national survey on labor migration in 2012.

from the ATO zone. The number of IDPs from the peninsula has stabilised a few months after the annexation of Crimea. But the number of migrants from the Donbas during 20142015 was steadily increasing and this process stopped only in 2016. The representatives of vulnerable groups dominate among IDPs. Almost half of them are disabled and the elderly persons, and the proportion of working age women is much higher than the proportion of working age men (22.4\% versus $12.7 \%$ as of 15.04 .2016$)$.

Besides ICB, there's also the Ministry of Social Policy of Ukraine that keeps account of IDPs. The ICB determines the number of people who asked for help in resettlement and placement, the Ministry of Social Policy keeps account of people, who applied for payment of their pensions or social assistance at the new place of residence. In reality, the statistics of the Ministry of Social Policy of Ukraine includes not only migrants, but also those people who actually live in the occupied territory and occasionally arrive to the areas controlled by central government to receive a pension or social assistance (so-called pension tourism). That means ICB has more accurate statistics that represent the migration of IDPs. The most number of immigrants (according to ICB) are located in areas of the Luhansk region that are controlled by central government (293.1 thousand), areas of the Donetsk region that are controlled by central government (227.7 thousand), Kharkiv region (196.7 thousand), Dnipropetrovsk region (78.2 thousand), Zaporizhzhia region (70.0 thousand), Kyiv region (60.0 thousand). In general, the share of IDPs in the total population of the regions placing consistently decreases with increasing distance from the zone of ATO.

Some people from the regions of intervention ask for asylum in foreign countries. According to information of the Office of the United Nations High Commissioner for Refugees, in August 2015 the number of Ukrainian citizens, who sent a request for refugee status in seven neighboring countries (primarily in Russia, Belarus and Poland), was 388.8 thousand people. There were also 732.0 thousand people [9] who stay in these countries on other grounds. Russian officials report a much higher number of people moving to this country, but that data is not confirmed. 
Additionally, the annexation of Crimea by Russia and the emergence of armed conflict in Eastern Ukraine have radically changed the dynamics and nature of labor migration from Ukraine. The national surveys on external labor migration in Ukraine were not conducted after 2012. That's why we can judge about the latest changes in migration process only from the data of sociological surveys, conducted by various institutions and expert assessments. They show some increase in the intensity of external labor migration compared with 2012 [10; 11]. The share of young people and high educational level among immigrants are increasing, reorientation of Ukrainian labor migrants from Russia to the EU continues to grow [12].

The expected visa-free regime for residents of Ukraine in the Schengen states is unlikely to affect the course of external labor migrations. According to international experts, the visa-free regime wouldn't ensure Ukrainian citizens with opportunities of non-restricted access to the EU. Those persons, who wish to enter the European Union, would still need to provide some documents for justifying the purpose of their visit, their financial security, etc. In contrast to the previous practice, these documents would be reviewed not by consulate employees, but by border guards [13]. Importantly, introduction of the free labor force movements between the EU and Ukraine is not currently under discussion. Based on the study of effects of the free trade area between Ukraine and the EU, implementation of the agreement cannot ensure the free movements of Ukrainian citizens in the EU Member States in full. However, this agreement can facilitate better conditions for those persons, who are already working in the EU, as well as for their families.

Another important feature of the recent labor migrations is associated with an increase in transition of labor migrants to permanent migrations (as such cases were rare in the 1990s). In particular, the long-term migrants, who have become accustomed in Southern Europe, increasingly bring their families to the recipient countries. It must be fully understood that some labor immigrants will not return to Ukraine at all.

While external labor migrations to the neighboring countries (Poland, Czech Republic, Hungary, and Russia) are usually associated with circular movements, i.e. short-term periodical trips with return to Ukraine, those laborers, who work in Italy, Spain, Portugal and Germany, are usually the long-term migrants. The increased length of stay in the recipient country is associated with a transition from temporary to permanent labor migrations, while a possibility of family reunification could lead to a departure of migrant's children from Ukraine. In the present conditions, these trends are intensified due to a deterioration of economic and political situation in Ukraine.

The natives of Donbas, who have received or would receive the legal grounds to stay in the EU, are unlikely to return to Ukraine. Also, some people, who have gone to Russia, would stay there. Foremost, those residents of Donetsk and Luhansk oblasts, who were born in Russia, would likely stay there, as well as their children.

Due to changes in the Ukraine's situation in the spring of 2014, it is logical to expect a recovery in labor migrations among those persons, who stopped their trips before, as well as an increase in their transition from temporary to permanent labor migrations. In addition, new contingents of people are becoming involved in external labor migrations, as evidenced by the results of the mentioned survey «Public opinion on social and economic orientations of the economically active population of Ukraine». As a result of consolidation of Ukrainian labor migrants in new places of residence in other countries, a share of people, who send money remittances or bring their earnings to Ukraine, would increase. In other words, an increase in the intensity of external labor migrations is expected in the short run, as well as further reorientation of migrations from Russia to the EU states (though migration to Russia would not stop completely), increased numbers of skilled specialists and youth among migrant 
workers, increased numbers of migrants with non-regulated status and increased trend of a transition from temporary to permanent migrations.

The long-term trends of migrations depend on the situation in Ukraine. If parameters of Ukraine's socio-economic development would stabilize at the level of 2014-2016 in the long-term run (i.e. no improvement would be observed), a transition from temporary to permanent external labor migrations would be strengthened. Moreover, some of the shortterm migrants would abandon the idea of return to Ukraine, not only the long-term migrants. A transition of temporary labor migrations into its permanent form will contribute to the labor shortage in Ukraine. Overall, the short-term migration scales will not change significantly: despite a transition of some migrants to long-term and permanent migrants, the contingents of short-term migrants would be replenished by those persons, who switched to the external labor migrations for the first time.

The described processes would take place even more intensively in case of deterioration of the Ukraine's situation. In this case, a majority of those persons, who preferred the shortterm trips at the beginning of the XXI century, would try to stay in the recipient countries. Moreover, emigration of highly skilled professionals from Ukraine would sharply increase. The new contingents would become involved in the short-term labor migrations much more intensively; still the short-term migrations would yield to the long-term migrations in a few years.

In case of improvement, the scales of the long-term migrations would stabilize, while involvement of new people to migrations would be limited by family members of the most successful long-term migrants. Moreover, in case of implementation of the relevant policy, a gradual return of the long-term migrants could be expected. The scales of the short-term migrations would gradually decline, as some migrants would start to focus on the domestic labor market. At the same time, the flow of immigrants from the Afro-Asian region would increase.

Conclusions. So, after the collapse of the USSR, the migration situation in Ukraine was transformed from population exchange with the other former Soviet countries and emigration of some ethnic groups to the domination of external labor migration of Ukrainians. After 2014 there is a revival of external labor migration in Ukraine, which is increasingly directed to the west. Most mobile are young and well educated people, especially men.

Demographic forecasts show that further reduction of the age groups that form the labor force is inevitable. The Government should develop and adopt a state program, which would deal with the return and reintegration of long-term migrants and also to develop this idea on regional level. It seems that the policy of returning migrants to Ukraine can only be fully implemented after the resolution of the armed conflict. The key element of such programs would be to promote potential business owners as the most promising way of directing money, earned by migrants, into Ukrainian economy. The programs should provide migrants with information and advice on starting and maintaining their businesses or employment, as well recognition of skills, which the migrants acquired abroad and psychological assistance for people in need. Tax and customs exemptions should be set for labor migrants, who have worked outside of Ukraine for at least two years and are planning to return to Ukraine. The opportunities for launching and maintaining a small business may be the mechanism that can encourage part of labor migrants to return home.

Considering economic sectors, where the majority of Ukrainian labor migrants are employed, there is a small chance that they will come back to Ukraine with modern innovations and technologies or will have business management skills. However, migrants returning from the EU are sharing the European values and standards of behavior, typical 
for societies of developed market economy. Additionally, these are the people who were selfsufficient or independent even before migration. This means that in terms of improving the business climate in Ukraine, the migrants, who have returned, and their family members will demonstrate a bigger willingness to be engaged in entrepreneurial activity. Within the framework of the study "Formation of the plan for actions, aimed at empowering local authorities to improve migration, social and educational policies for the benefit of children, women and local communities in Ukraine" requested by IOM in 2010, children of labor workers, who have reached the age of 18 and who have the right to financial entrepreneurship, showed that even in unfavorable conditions in Ukraine, children of labor migrants are willing to engage in business sphere; more than half of them see the prospects for starting and maintaining business together with their parents, who are now abroad. Most of the migrants' children save money on the more or less regular basis, nearly a third of them have (along with parents) money needed to start a business [14].

It is important to intensify the efforts to enact bilateral agreements with the recipient countries for Ukrainian migrants about social security, recognition of educational documents (nostrification) and documents proving professional qualifications, driving licenses, etc. Moreover, there should be a discussion about accounting for the labor of seniors abroad and inclusion of this labor into their pensions in Ukraine. It is also important to start negotiations with the governments of recipient countries to extend the European voluntary return programs (Assisted Voluntary Return). Another essential area of international cooperation is the development and implementation of programs of circular migration: it is beneficial not only for Ukraine, but also for the recipient countries. It means that Ukraine has real opportunities to negotiate with the EU on the involvement of relevant countries in financing these programs.

In order to strengthen the ties between Ukrainian labor migrants and homeland, to increase the level of returns of labor migrants, Ukraine should expand opportunities of distance education for children of labor migrants, who, together with their parents, are currently living outside of the state. Additionally, Ukrainian secondary schools abroad could be created with the involvement of local funds and recruitment of the teaching staff among labor migrants.

In order to minimize the loss of intellectual potential and to prevent the outflow of youth, the Ukrainian state should, firstly, extend the system of grants for talented youth (including based on involvement of the European donors). Secondly, the Government should introduce procedures of arranging contracts with graduates of certain professions, whose education has been sponsored by the state to regulate temporary and permanent emigration of these specialists.

In addition, the procedure of recognition of foreign diploma, academic degree or qualification (nostrification) needs a substantial change. Currently, this procedure is time consuming and expensive (nostrification includes the authentication of documents and verification on compliance with the diploma's educational degree of qualification level in Ukraine) and it's recognized by the youth as one of the obstacles to coming back to Ukraine.

The EU countries should continue their practice of legitimizing Ukrainian migrants, maintaining programs of circular migration and promoting tolerance to Ukrainian migrants among the local population.

The strategy of the state policy on IDPs should be based on a differential approach to different categories of immigrants. Implementation of this approach requires constant 
monitoring of sentiments of IDPs and their intentions towards future plans about relocation. It is necessary to introduce a systematic survey of IDPs on these issues.

Integration of IDPs, who do not wish to return, should include assistance in arrangement of a new residence and promotion of tolerance between migrants and local inhabitants. Families, who plan to stay, should be ensured with housing, means of providing financial support for the purchase or repair of their own homes; repairing centers for collective accommodation and transfers of ownership in housing; construction of housing with further transfer of ownership. It also makes sense to use social criteria for providing housing (families with many children, single parent families, etc.).

At the same time it's important to conduct an information campaign among the population of Ukraine on unprejudiced and tolerant attitude to IDPs from the Eastern part of Ukraine. There were several reports about conflicts between IDPs and the local population during 2014 in the media. Some situations can be observed even today. However, there are no reasonable grounds to speak about the massive conflicts - it's more likely that some resonant cases gained publicity. The impact of such events on public opinion should be minimized. In addition, the government agencies and international organizations should work with local authorities (especially with employees involved in the arrangement of pensions and social assistance) toward raising awareness of the needs of IDPs and to avoid prejudice against migrants.

\section{ЛІТЕРАТУРА}

1. Малиновська О. Мігранти, міграція та Українська держава: аналіз управління зовнішніми міграціями. - К.: НАДУ, 2004. - 236 с.

2. Україна: Міграційний профіль [Електронний ресурс]. - Режим доступу: http://kr.dmsu.gov.ua/ images/files/UKR_Migration_\%20Profile_2013.pdf

3. Про правовий статус іноземців та осіб без громадянства. Закон України від 22.09.2011p. № 3773VI [Електронний ресурс]. - Режим доступу: http://zakon4.rada.gov.ua/laws/show/3773-17 (знято 3 сайту 21 жовтня 2016 р.)

4. База даних UNESCO. Сайт UNESCO [Електронний ресурс]. - Режим доступу: http://data.uis. unesco.org (accessed 2016-10-21)

5. Сайт CEDOS [Електронний ресурс]. - Режим доступу : http://cedos.org.ua/data/CEDOS_ UKRstud_abroad.xlsx

6. Ukrainian External Labor Migration - Kyiv, 2009.

7. Report on the Methodology, Organization and Results of a Modular Sample Survey on Labor Migration in Ukraine, International Labor Organization, Decent Work Technical Support Team and Country Office for Central and Eastern Europe (DWT/CO-Budapest) Budapest: ILO, 2013.

8. Сайт Державної служби України з надзвичайних ситуацій [Електронний ресурс]. - Режим доступу : http://www.dsns.gov.ua/ua/Mizhvidomchiy-koordinaciyniy-shtab.html (знято з сайту 16 травня 2017 р.).

9. Сайт Управління Верховного комісара ООН у справах біженців. Регіональне представництво у Білорусі, Молдові та Україні [Електронний ресурс]. - Режим доступу : http://unhcr.org.ua/ en/2011-08-26-06-58-56/news-archive/1244-internal-displacement-map (знято з сайту 21 жовтня 2016 p.).

10. Малиновська О.А. Українсько-Польський міграційний коридор: особливості та значення // Демографія та соціальна економіка. - 2015. - № 2 (24). - С. 31-40. - doi: https://doi.org/10.15407/ dse2015.02.031.

11. Позняк О. Оцінювання наслідків зовнішньої трудової міграції в Україні // Демографія та соціальна економіка. - 2016. - №2 (27). - C. 169-182. - doi: https://doi.org/10.15407/dse2016.02.169

12. Ukrainian Migration in Time of Crisis: Forced and Labour Mobility / Dušan Drbohlav, Marta Jaroszewich (ed.). - Prague, 2016. 
13. Consequences of Schengen Visa Liberalisation for the Citizens of Ukraine and the Republic of Moldova. Weinar A., Korneev O., Makaryan S., Mananashvili S. [Електронний ресурс]. - Режим доступу: http://www.migrationpolicycentre.eu/docs/RR\%202012\%2001\%20-\%20visa\%20final.pdf (знято 3 сайту 21 жовтня 2016 р.).

14. Pozniak $O$. Investigation of Entrepreneurship Potential of Ukrainian Labor Migrants // Zeszyty Naukowe. - 2013. - № 4 (42). - P. 45-54.

\section{REFERENCES}

1. Malynovs'ka, O. (2004). Mihranty, mihratsiya ta Ukrayinska derzhava: analiz upravlinnya zovnishnimy mihratsiyamy [Migrants, Migration and Ukrainian government: analysis of the management of external migration]. NADU [in Ukrainian].

2. Ukraina: Mihratsiinyi profil. [Ukraine. Migration profile.] (2014). kr.dmsu.gov.ua. Retrieved from http://kr.dmsu.gov.ua/images/files/UKR_Migration_\%20Profile_2013.pdf [in Ukrainian].

3. Zakon Ukrainy vid 22.09.2011 r. № 3773-VI «Pro pravovyi status inozemtsiv ta osib bez hromadianstva». [Law of Ukraine of 22.09.2011 No3773-VI «On Legal Status of Foreigners and Persons without Citizenship' Law of Ukraine»]. (2011, 22.09.). zakon4.rada.gov.ua. Retrieved from http://zakon4.rada. gov.ua/laws/show/3773-17 [in Ukrainian].

4. UNESCO (2016). data.uis.unesco.org. Retrieved from http://data.uis.unesco.org [in English].

5. CEDOS (2016). cedos.org.ua. Retrieved from http://cedos.org.ua/data/CEDOS_UKRstud_abroad. xlsx [in English].

6. Libanova, E. (Eds.). (2009). Ukrainian External Labor Migration. Kyiv.

7. Libanova, E. (Eds.). (2013). Report on the Methodology, Organization and Results of a Modular Sample Survey on Labor Migration in Ukraine, International Labor Organization, Decent Work Technical Support Team and Country Office for Central and Eastern Europe (DWT/CO-Budapest). Budapest: ILO.

8. Derzhavna sluzhba statystyky Ukrainy: Ofitsijnyj sajt [State Statistics Service of Ukraine: Official site]. ukrstat.gov.ua. Retrieved from http://www.dsns.gov.ua/ua/Mizhvidomchiy-koordinaciyniy-shtab.html [in Ukrainian].

9. Upravlinnia Verkhovnoho komisara OON u spravakh bizhentsiv. Rehionalne predstavnytstvo u Bilorusi, Moldovi ta Ukraini. [The Office of the United Nations High Commissioner for Refugees. Regional representative for Belarus, Moldova and Ukraine]. unhcr.org.ua. Retrieved from http://unhcr.org. ua/en/2011-08-26-06-58-56/news-archive/1244-internal-displacement-map [in English].

10. Malynovs'ka, O. (2015). Ukrainsko-Polskyi mihratsiinyi korydor: osoblyvosti ta znachennia [UkrainianPolish migration corridor: features and importance]. Demohrafiia ta sotsialna ekonomika - Demography and social economy, 2(24), 31-40. doi: https://doi.org/10.15407/dse2015.02.031 [in Ukrainian].

11. Pozniak, O. (2016). Otsinyuvannya naslidkiv zovnishnoyi trudovoyi mihratsiyi v Ukrayini [Evaluation of Consequences of External Labor Migration in Ukraine]. Demohrafiia ta sotsialna ekonomika - Demography and social economy, 2(27), 169-182. doi: https://doi.org/10.15407/dse2016.02.169 [in Ukrainian].

12. Drbohlav, D. \& Jaroszewich, M. (Eds.). (2016). Ukrainian Migration in Time of Crisis: Forced and Labour Mobility. Prague.

13. Weinar, A., Korneev, O., Makaryan S. \& Mananashvili, S. (2012). Consequences of Schengen Visa Liberalisation for the Citizens of Ukraine and the Republic of Moldova. migrationpolicycentre.eu. Retrieved from http://www.migrationpolicycentre.eu/docs/RR\%202012\% 2001\%20-\%20visa\% 20final.pdf [in English].

14. Pozniak, O. (2013). Investigation of Entrepreneurship Potential of Ukrainian Labor Migrants. Zeszyty Naukowe, 4(42), 45-54 [in English].

Article received on 22.05.2017.

Стаття надійшла до редакції журналу 22.05.2017. 